\title{
Specimens of Somali Tales.
}

\section{E. S. Hartland}

To cite this article: E. S. Hartland (1904) Specimens of Somali Tales., Folklore, 15:3, 316-326, DOI: $10.1080 / 0015587 X .1904 .9719412$

To link to this article: http://dx.doi.org/10.1080/0015587X.1904.9719412

$$
\text { 曲 Published online: } 06 \text { Feb } 2012 .
$$

5 Submit your article to this journal $₫$

Џll Article views: 1

Q View related articles ¿ 


\section{COLLECTANEA.}

Specimans of Somali Tales.

(Collected by J. W. C. Kirk, Lieut. VI. King's African Rifles.)

THE following stories are offered to the student of folklore for what they are worth. He will perhaps be able to determine how far they are the genuine native product, and how far they are borrowed from Arabic or other sources. As a matter of fact the narrators were quite unacquainted with Arabic, with the exception of the Mullah of Burao, who told me the story No. XI. They were all collected from men of the Ishhak tribes from the Burao district, and I have in each case stated under the title the name of the individual narrator with his tribe and subtribe. Nos. I.-V. may be classified as romantic fiction, VI.-VIII. as gnomic or proverbial in their purport, and IX.-X. as beast fables. No. XI. looks like a variant of the story of the sons of Judah, and may, I dare say, have been derived by my priestly informant from Mohammedan literature.

I may add that all these tales were told me in the native language, and that $I$ have in my possession copies of the Somali originals (except XI.), which I hope to publish shortly. There are no signs of the stories having been handed down word for word, their phraseology being that of the spoken language of the day, whereas Somali songs are full of obsolete forms and expressions, often unintelligible to the average Somali.

Dr. A. W. Schleicher's Somali Texte, by Reinisch (Wien, 1900), contains an excellent collection of Somali tales.

I.

Habiyo Butiya (Lame Llabiyo).

(Mohammed Jibril, Habr 'Toljaala, Musa Abokr, clerk, aged about 26.)

There once was a Sultan who had a son, whose mother was dead. But the Sultan married another wife, and went on a 
pilgrimage. Now a certain Jew was a friend of the Sultan's wife, but the Sultan's son and the Jew were enemies. The Jew said to the woman, "Let us kill the boy." So she mixed some poison in his food. But the boy had a mare, who knew everything, and the mare said to the hoy, "Don't eat the food"; and when the food was put before him, the boy refused it. The next day the Jew came to the Sultan's wife and said, "When the Sultan comes back, say you are sick, and when he asks what will cure you, tell him the liver of the mare." The next day the Sultan came. Then she laid the skin on the bed and placed under it some fig-leaves, and when she lay down the leaves crackled. Then the Sultan said, "What is the matter with you?" and she said, "I have a pain in my ribs." "What will cure you?" he said; and she answered, "The liver of your son's mare." The Sultan called the boy and said, "I intend to kill your mare for your stepmother." And the boy said, "Very well, but let me take a ride on her this evening." In the evening the boy rode the mare, and said to his father, "Good-bye, Father," and departed with the mare. Ile went to a town, and near the town he saw six girls washing at a well. The youngest of the girls saw him, and when she saw the man, she ran away from the well, being ashamed in front of the man. Then he singed the tail of the mare, who went up into the sky. The young man then pretended to be a cripple, and went into the town, and there became a servant.

Later on the daughters of the Sultan said, "We wish to marry." The Sultan beat his drum, and announced, "My daughters wish to marry." Then the rich young men came together, and the girls were brought, and the people stood in the plain. Then the girls were asked, "Are the men you want all here?" And the young girl said, "The man I wanted is not here." The slave girls who were summoning the men were told to call all the men in the town, so they called the young cripple, Lame Habiyo. Then the Sultan asked the girls, "Are the men all here?" And they said, "Yes." The girls were given six oranges, and they were told, "Let each girl hit the man she wants." The five other girls hit five rich young men; the young girl hit Lame Habiyo. Then her father and mother were so struck with horror that they lost their sight, and the young man married the girl. On the next day they were told, "That which will cure the Sultan and his wife is rhinoceros' milk." And the young 
men who married the five girls were given five good horses, and Lame Habiyo was given a donkey, and they left the town. There came to Lame Habiyo the mare, whose tail he had burned, and he put on his gold dress and sword, and mounted the mare. The mare flew up and reached the sky. Then he went to a place where rhinoceroses are born. A young rhinoceros he cut open, and opened out the skin, and made a figure from it. In the afternoon the mother rhinoceros came, and Lame Habiyo pretended to be the young one. The first portion of milk he milked into one skin, and the second portion he milked into another skin. Then the rhinoceros went to graze. Then the young man threw away the figure, and took the milk. He went to a tree and tied his mare to it. While he slept under the tree the five young men who married the other girls came to him and said, "Salam Alekum." And Lame Habiyo said, "Alekum Salam." Then he said, "Where are you going?" And they said, "We are looking for rhinoceros' milk." Then he said, "I have some rhinoceros' milk. What will you give for it?" And they said, "Whatever you wish." Then he said, "Wealth do I not want, but I will brand my name on the hinder parts of each of you." Then they said, "Agreed." So he branded his name on the hinder parts of all five. Then he gave them the first milk, and the second milk Lame Habiyo took for himself. They went to the town where the Sultan lived, and took the milk. The five young men carried the milk, and it was poured on the eyes of the Sultan, but was of no use. Another day Lame Iabiyo gave his milk to his wife and said, "Let not your father and mother see you when you pour it in." Then she took the milk and she poured it in. And the eyes of the Sultan and her mother were opened. Then the girl came running away and came to her house. Then the Sultan learned that Lame Habiyo had opened his eyes, and the Sultan called the other young men that married his daughters, and he said, "To the young man Lame Habiyo who married my young daughter have I given authority over my town, and you, be his servants." Then Lame Habiyo said, "O, Sultan, 'twas I who did bring you the rhinoceros' milk, and my name is on the five young men's hinder parts." And they looked, and the name of Lame Habiyo was found. Afterwards Lame Habiyo became Sultan. 
II.

Perseus and Andromeda.

(Mohammed Jibril.)

There were a brother and sister who kept a cow. They dwelt in a deserted place, and the brother used to go with the cow, while the sister used to sit in the house, and at night they met in the zariba. 'The sister was of great beauty, and men asked for her, but her brother refused to let the girl be married. One day some men came into the house for the girl, and they conversed; and the brother came in in the evening and found that men had come for his sister, but he said nothing. The next day the men returned to the girl and said, "We think of killing your brother. When is he engaged ?" And the girl said, "When he is milking the cow." In the evening they came as he was milking the cow, and jumped in over the fence, and when he saw the enemy he drew his sword. His sister seized his hair; but he cut it off, and jumped over the fence, which cut off his genitals, and he escaped. He went to a town where there was a girl tied to a tree, and he said, "Who are you, girl?" and she said, "My father is the Sultan of the town." And he said, "Why are you tied up here?" and she said, "I ain tied up for a dragon which will come and eat me." Then he said, "When does it come?" and she said, "In the evening." And he said, "When the dragon comes, what will it do ?" and she said, "First it will drink the water, and afterwards eat me," and he replied, "Very well." Then the dragon came and went down to the water, but the young man drew his sword and struck it on the head and it died. Then he led away the girl and brought her to the town, and the people of the town came running to him as he led the girl, and they said, "What is this ?" and he said, "I have killed the dragon."

Then he was brought to the Sultan, and they said, "This man has killed the dragon." And the Sultan bade him marry his daughter. So thereupon the man married her.

III.

The Girl without legs.

(Mohammed Jibril.)

A Sultan had a daughter, and the daughter used to be taught 
the Koran. One day the Sultan went on a pilgrimage, and entrusted his daughter to a priest and said, "Continue to teach that girl the Koran." The priest coveted the girl, wishing to lie with her, but the girl refused. One day she said, "Come to me to-morrow." On the day arranged she removed from the house the ladder by which the priest used to ascend. He then sent a letter to her father, and he wrote, "Your daughter has become a whore." The Sultan returned from the pilgrimage, and he was angry with the girl, and he handed her over to some slaves, and he said, "Cut that girl's throat." Then the slaves took the girl, and brought her to a wooded place, and they cut off her legs while they dug her grave. While they were digging the grave she crawled away, and went into some trees and hid. When the slaves had dug the grave, they looked in the place where she had lain and could not find her. Then they slew a gazelle, and the gazelle's blood they poured into a bottle, and brought the blood to the Sultan and said, "We have slain the girl." One day later a caravan passed by the place and camped where the girl lay. In the afternoon as the party were loading up the camels, they saw the girl sitting under a tree. A man took the girl, and put her on a camel, and brought her to the town they came to. The man who took the girl put her to live in a house. Later on the son of the Sultan saw the girl's face, and the young man saw that her face was beautiful, and he said to the man whose house she dwelt in, "Let me marry that girl from you." And the man said, "The girl has no legs." Then the Sultan's son said, "I will marry her, give her to me." And so the man said, "Well and good." And the Sultan's son married her. She bore two children, and while she was with child the young man said, "I am going on a pilgrimage." $\Lambda$ nd he left her a ram, and went on the pilgrimage. While he was away on the pilgrimage his wife had a dream, and she dreamed that two birds sat upon her two legs, and her legs had grown out, and that she made the pilgrimage. In the morning at break of day she saw the two birds sitting upon her two legs, and the legs had grown out. After daylight she took her two children and the ram and the two birds and went on the pilgrimage. She came to a building at the half way, and there came to her her father and her brother and the priest and her husband, none of whom knew her. She told stories to her children, and she related all that had happened to her, and her father heard and the priest. 
Then the priest tried to run away, but the Sultan said, "Sit down until the story is finished." Then the Sultan, the girl's father, cut the priest's throat, and the girl and her father and husband they went on together and made the pilgrimage. And so the girl and her father were reconciled.

IV.

The Sultan's Wife.

(Mohammed Jibril.)

There was a Sultan who had a son, and his son said, "I want to marry," So the Sultan gave him many presents, and also a ship. The Sultan's son set sail and came to a town, and when he arrived at the town he became friends with a Sultan, and the Sultan gave him a house. The young man made a hole between the house he was in and the Sultan's house, and he became friends with the Sultan's wife. One day the young man said to the Sultan's wife, "Make some food for me just as you are accustomed to make it for your husband." And he went to the Sultan, and said, "Tonight will you take food with me?" And the Sultan said, "Well and good." And the young man said to the Sultan's wife, "Tonight when I and the Sultan are having our food, I want you to serve us with the food." And the woman said, "The Sultan will know me." Then he said, "He will not know you, I will say you are my wife." And she said, "If he does not know me, I will go with you and be your wife." At night the Sultan came home and dressed himself, and came to the young man's house. And his wife passed through the hole in the house, and came to the young man's house. Then she served the food to the Sultan and the young man. The Sultan recognised his wife, and got off his chair, and went to his house. Before he reached his house, the woman passed through the hole and sat upon her bed, and the Sultan saw her. When he saw her he straightway came back to the house of the young man, while the woman came through the hole, and still he saw her. The young man, who was dining with him, said to the Sultan, "Did you think this woman who is serving our food was your wife? The woman is my wife," he said, and the Sultan "Vown. The next morning the young man said, "I am sailing." "Very good," he answered. And the young man arranged with vor, xv. 
the Sultan's wife, and said, "In the morning come through that place, I am sailing." So the woman came through and came to the young man, and he took her to the ship, and sailed. And the young man having run away with the Sultan's wife married her.

V.

(Ismail, Habr Toljaala, Ahmed Farah, professional poet, aged about 24.)

There is a story that a man was riding a horse, and there came to him an old woman, who said, "Where are you going?" And he said, "I am going to that town." And she said, "In that town people are slain and eaten; do not go in lest they slay you." And he answered, "Still I am going in." Then she said, "The town has a Sultan, and the Sultan has a daughter, and the daughter's sash is a snake, and the snake eats the people. And there is a camel who eats the people; he sits in front of the house, over there upon a bed." And she said, "See, my man, if you are going to the house, run and enter the house of the Sultan's daughter." And he said, "The man told me the dog eats the people, and the camel eats the people, and the snake eats the people. How am I going to pass them ?" And the woman said, "Take this grass, and let not the camel eat you, but when you pass the house you are going to, put the grass in at the door, lest it eat you. And for the dog, take this piece of meat, and put it near the dog, and let him eat it and not you. And for the snake, which is tied round the girl's waist, take this stick, and place it on the snake's head, and then the snake will die. After you have done this, enter the house and go to the girl, and then marry her." So he married the girl.

VI.

Misfortunes never come singly.

(Ismail.)

There is a story that a man once loaded his water-camels and took them to the well, and went to draw water. When he went to draw water he tied his camels together. When he was in the nullah be left six camels behind, while he led the other six. When 
he was some distance off, the six camels that were left behind were not to be seen. So he ran back, and came up to find six lions eating the six camels. Then he left them, and returned to the other six camels, and found six other lions eating these. Then he took a waterskin from the camels, and came to his home, to find his family looted by an enemy.

\section{VII.}

Hore to choose a roife.

(Ismail.)

$\Lambda$ man had a son, and the son said to his father, "Father, I want to marry a wife." Then his father said, "Do you take a widow." So he took a widow, and his father said, "Marry her." So he married her. Then his father said, "Tie her with a rope, and when she speaks to you, untie the rope." So he tied her with a rope, and the woman said, "This is not what I have been accustomed to see. What are you doing with me?" Thereupon he untied the rope. In the morning his father came and said, "What did she say?" And he answered, "She said to me, "This is not what I have been accustomed to see. Why are you doing that to me?" "Then his father said, "Send her away." That was one.

The father said to his son, "Take another wife, take a grown girl." Then he said, "To-night tie her with a rope, and when she speaks to you, untie it." So he tied her, and she said, "This is not what I have been accustomed to hear. Why are you tying me with that?" So he untied her. In the morning he came to his father and he said, "She said, "This is not what I have been accustomed to hear. What are you doing to me with the rope?" Then his father said, "Send her away too." And that was another.

Then his father said, "Do you go and take a nice young girl." So he took one, and he said, "To-night tie her with a rope, and when she speaks to you, untie it." So the young man did so and went to sleep, and was asleep all night. In the early morning the girl woke him up, and said, "The rope with which you tied me has fallen off and is not tied to me, tie it upon me." And in the morning he told his father. "Father, she said, "The rope 
has fallen of and is not tied to me, tie it upon me.'" Then his father said, "Keep that one, she is the right one." So she was the one he afterwards married.

\section{VIII.}

The Blind Man.

(Ali Sumattar, Habr Yunis, Musa Arreh, officers' cook, aged about 40.)

In a certain place many men were talking, and there were two men, one of whom was blind and the other was not blind. The man with sight said, "Why do you talk with a blind man? He can see nothing." And the blind man said, "How do you know a blind man?" The other one said, "We know a blind man, he is a man who sees nothing." Then the blind man said, "He that is blind is the man who knows nothing, he is blind."

IX.

(Ismail.)

It is said that the Hyana owned flocks and Man had none. One day Man was looking after the Hyæna's flocks, and the Hyæna went to the council. After this Man thought, and he said, "Let us stenl the Hyæna's flocks while he is away at the council." So Man put the flocks in a zareba; and night came, and when it was night they were driven off. The Hyæna howled, and went to the other animals, and he said, "See, I have been looted." Then they said, "Let us attack." They came along, and arrived at a pool of water, and the male Dikdik said, "If you do not let me come to the pool you shall not drink." "Sir, we will drink; leave us," they said. Then he scratched sand into it until the water was gone; and they died of thirst when they found no water.

X.

(Ismail.)

It is said that a Camel possessed altogether a Snake, a Zareba, a Fire, a Flood, and a Lion, and Deceit, and Honesty. Those seven the Camel owned. One day Deceit said, "We might steal 
the Lion from that big Camel ; let us kill the Lion." The others said, "How are we to kill him ?" Then she said, "Let the Snake bite the Lion, and when you have bitten him go into the Zareba." So he bit him and went into the Zareba. Then she said, "O Fire, burn up both the Zareba and Snake." So the Fire burned both Zareba and Snake. 'Then she said, "The Fire has killed the Snake and the Fence, let the Flood too put out the Fire." After this Honesty said, "The Flood does not travel on the mountain, but only in the nullah; let us travel on the mountain with the Camel." So they travelled on the mountain, and then Ueceit said, "Let us slay the Camel." So they slew her, and cooked the steak, and gulped down the steak, and except the steak nothing else of the Camel did they eat. And the meat stuck in their throats, for it was a big piece, and could not pass through their mouths. So they died.

XI.

Gerhajis and Arab.

(Haji Ali Mohammed, Habr Yunis, Abdallah Ismail, priest, aged about 50.)

Gerhajis and Arab were the twin sons of Sheikh Ishhak (the ancestor of one of the two great divisions of the Somalis) by his wife Magado. Before birth one child put out his hand, and the mother wishing to mark him wanted to put a ring on his finger, but, no ring being available, tied on a piece of thread round the little finger. Then the hand was withdrawn. Subsequently one boy was born, but no thread was found on his finger; this child was called Arab. Later, the other was born, having the ring of thread, and called Gerbajis.

When they were grown up, there was a dispute as to which was the elder. For the elder son, besides becoming head man, must always be married before the younger is allowed to do so. But it was decided that the one that put his hand out, namely Gerhajis, was the first born

$$
\text { J. W. C. KIRK. }
$$

Norr.--These Somali tales are interesting. Several of thcm, however, are defective, which perhaps may be accounted for by 
the fact that they were told by men. Women are notoriously the best tellers of Märchen; and a woman would have been more likely to remember and reproduce the details. In the first story, for instance, the omissions are numerous. The singeing of the mare's tail is an incident I do not remember reading before; but why did Habiyo adopt this method of causing the nagical beast to disappear? There must have been, as in other versions there is, a conversation with her. Probably she herself originally informed the hero of his stepmother's plot, and concerted with him the measures he was to take. Again, why did the sultan's youngest daughter choose the cripple for a husband? We know from other versions that she had previously seen him and penetrated his disguise. But the incident, a necessary link in the story, is wanting here,

The curious incident in the second story of the hero's mutilation is paralleled in the ancient Egyptian Tale of the Two Brothers. It is also worthy of note that in the Japanese variant of the Perseus and Andromeda legend the dragon drinks before attacking his prey. (See Campbell, My Circular Notes, vol. i., p. 326; Aston, Nihongi, vol. i., p. 52.) The fourth story depends on the incident of the hero's digging a tunnel from his residence to the heroine's apartments in her husband's house. It is obvious that this incident can hardly be natural among the Somalis. In fact, the story is well known in the Mediterranean area, and has doubtless been brought, like several of the others, by Arabs to Somaliland. The modern phraseology of the originals, referred to by Lieutenant Kirk, strengthens the probability of importation.

\section{E. S. Hartland.}

\section{Notes from the Upper Congo, III.}

$$
\text { (Vol. xii., pp. 18r, 458.) }
$$

I PURPOSE now to give you two of the legends told here about Libanza, the nearest equivalent we can get to God. It will be interesting to note, before passing on to the legends, some of the notions the natives have respecting God. Their ideas are very nebulous. To them apparently the Godhead consists of four 